\title{
The Measurements of Budgetary Slack: The Empirical Evidence of Listed Companies in Thailand
}

\author{
Pornpan Damrongsukniwat, Danuja Kunpanitchakit, and Supol Durongwatana
}

\begin{abstract}
This study introduces an objective measurement of budgetary slack based on ex post measure of firm's annual budget achievability with the exclusion of earnings management through discretionary accruals rather than the traditional subjective measurement based on management's perceptions. Also, this study empirically examines the association between budgetary slack and its determinants under various budgetary slack measurements. This study uses data from survey questionnaires and data from the annual financial statements for the year ended 2009 of listed non-financial and non-rehabilitation companies in Thailand. The population covers 387 firms and there are 38 returned and usable questionnaires which is $10 \%$ response rate. Although the objective measurement of budgetary slack is statistically found to be positively related to the traditional subjective measurement, the suggested objective measurement is considered to be a superior one. Moreover, the association between budgetary slack and its determinants is relatively sensitive to the measurements of budgetary slack.
\end{abstract}

Index Terms-Budget achievability, budgetary slack, discretionary accruals, earnings management.

\section{INTRODUCTION}

Although budgeting is the cornerstone of the management planning and control processes in nearly all organizations and is widely used, it is far from perfect. When organizations use budgets for performance evaluation, traditional budget-based compensation plans provide economic incentives for subordinates to misrepresent their productivity and build slack into the budgets. The slack then creates budget bias and can reduce firms' profits due to costly planning errors and greater compensation or perquisite consumption for subordinates.

Budgetary slack is created by managers who can manage to conceal some private information from their supervisors and deliberately misrepresent that information in order to maximize their own utility through the introduction of slack. Budgetary slack in this paper is defined as the subordinates' intentional biasing of performance targets below their expected levels which is consistent with [1]. Empirical evidence suggests that, in most entities, significant amounts of budgetary slack exist. Ref. [2], [3] Examine the determinants of budgetary slack and also report that, on average, manufacturing companies in Thailand have moderate level of budgetary slack.

Manuscript received September 10, 2013; revised November 11, 2013.

P. Damrongsukniwat and D. Kunpanitchakit are with the Department of Accounting, Faculty of Business Administration, Kasetsart University, Bangkok, Thailand (e-mail: o_nong@hotmail.com).

S. Durongwatana is with the Department of Statistics, Faculty of Commerce and Accountancy, Chulalongkorn University, Bangkok, Thailand.
Traditional budgetary slack measurements are subjective measures based on respondents' subjective view, i.e., "managers' perception of the target achievability". These types of measurements have long been proposed and utilized in most budgetary slack studies even though they possess drawback, e.g., respondents may have different perceptions under the same environment. As such, an objective measurement of budgetary slack based on numerically measurable and insensitive to each respondent's perception is sought to ensure its reliability. Nevertheless, budgetary slack is not directly observable. Thus, this study intends to propose an objective measurement of budgetary slack in the hope to improve the reliability and the quality of such.

This study employs both primary data from mailed survey questionnaires and secondary data from the annual financial statements in the analysis. The sampled firms are companies listed on the Stock Exchange of Thailand (SET) and the Market for Alternative Investment (MAI) as of the year ended 2009, all of which use budget for performance evaluation. This study excludes companies in financial industry and companies under rehabilitation for the reason that their financial reporting requirements and their characteristics of business operation are different. Survey data on budget figures of the year 2009, perceived budget achievability, and all determinant factors are gleaned from the management at the corporate level of the listed companies to match their companies' annual financial statements. The final set of samples in this study consists of 38 firms, representing $10 \%$ of the total population (387 firms). The small sample size is due to the difficulty in obtaining the firm's internal and confidential data.

Generally, the results show that the suggested objective measurement of budgetary slack is significantly, positively correlated $(r=0.58, p<0.01)$ with the subjective measurement (reversed score of perceived difficulty of budget achievability); however, the correlation between the suggested objective measurement and another subjective measurement (perceived ease of budget achievability) is insignificant. Although the objective and the subjective measurement of budgetary slack are significantly and positively correlated, we still believe that the objective approach of budgetary slack measurement suggested in this study do provide another objective measurement of slack. The inconclusive results of the association between budgetary slack and its determinants in prior research might result from the different measures of budgetary slack. Therefore, this study empirically examines the association between budgetary slack and its determinants by comparing the objective and the subjective slack measurements. The empirical results in our study corroborate the fact that the association between budgetary slack and its determinants is sensitive to slack measurements. 
This study contributes to prior literature by adding to it an objective measurement of budgetary slack as prior survey studies usually measure slack from a subjective view, although it is a perceptual dependent variable. Besides, this study empirically examines the association between budgetary slack and its determinants by comparing the objective and the subjective slack measurements which the results reveal that the association between budgetary slack and its determinants is sensitive to the measurements of slack, i.e., subjective and objective measurements or even between the two subjective measurements.

\section{LITERATURE REVIEW}

\section{A. Budgetary Slack}

Budgetary slack has been defined in the literature under a variety of ways, e.g., it can be defined as the intentional biasing of performance targets below their expected levels [1]; the consumption of organizational resources by employees in excess of what is required [4]; the amount by which managers overstate their needs for resources to complete a task or understate their productive capability when given the opportunity to influence the standard against which their performance will be evaluated [5]; and the difference between the subjects' expected performance and chosen budget [6].

Consistent with [1], the definition of budgetary slack in this study is the subordinates' intentional biasing of performance targets below their expected levels.

Budgetary slack creation often takes place when tight results controls are in use. That is, when employees, mostly at management levels, are evaluated primarily on whether or not they achieve their budget targets [7]. Managers who miss their target face the prospect of interventions in their jobs, the loss of organizational resources, the loss of annual bonuses and pay raises, and sometimes even the loss of their job [8]. So they may look for ways to protect themselves from the downside risks of missing budget targets and the stigma attached to underachievers [9]. Possible ways of protection can be obtained by negotiating for highly achievable targets (i.e., budgetary slack creation).

A large body of archival research presents substantial evidence that significant amounts of budgetary slack exist in most business organizations, as estimated by the magnitude of slack to be as high as $20 \%$ - $25 \%$ of budgeted operating expenses [5], as well as by the prevalence of managers willing to admit that they engage in budgetary slack creation to be as high as $80 \%$ of the managers interviewed [10]. In Thailand, [2]-[3] perform survey research and also report that, on average, Thai manufacturing companies have moderate level (level four of seven-point Likert scale) of budgetary slack.

\section{B. Earnings Management}

In accordance with General Accepted Accounting Principles (GAAP), financial accounting information is prepared based on the accrual basis. In the accrual basis, the effects of transactions and events are reported in the financial statements of the period to which they occur, rather than when cash or cash equivalent is received or paid. Accruals play an important role in financial reporting. There are two aspects of accruals' role. In the first aspect, accruals play a role in producing a reliable and more timely measure of firm performance, so earnings are able to reflect firm performance better than cash flows and the discretionary component of accruals helps improve such ability. By contrast, in the second aspect, some studies find that earnings play a central role in measuring the enterprise's performance while accruals play an important role in obscuring true underlying firm performance via an introduction of discretionary accruals, which is commonly known as earnings management.

Earnings management can be defined as non-neutral financial reporting in which managers intervene intentionally in the financial reporting process to produce some private gains [11]. It occurs when managers use judgment in financial reporting and in structuring transactions to alter financial reports either to mislead some stakeholders about the underlying economic performance of the company or to influence contractual outcomes that depend on reported accounting numbers [12]. In other words, earnings management is a strategy used by company's management to deliberately manipulate the company's earnings so that the figures match a pre-determined target.

Existing literature demonstrates that executives engage in earnings manipulation both upward and downward management through accruals for a number of incentives, e.g., to maximize their compensation, to avoid debt-covenant violation, to meet and beat earnings benchmarks, and to reduce political visibility (e.g., [13]-[16]).

\section{Determinants of Budgetary Slack}

Prior literature suggests the association of certain factors with budgetary slack (e.g., [6], [17]-[20]). This study classifies those key factors into environmental factor (environmental factor), organizational factors (information asymmetry, budget emphasis evaluative style, participative styles, reward systems, and budget-based resource allocation), and individual factors (ethical concerns, reputation concerns, and fairness concerns).

\section{RESEARCH DESIGN}

\section{A. Sample and Data}

The sample used in this study consists of the companies listed on the Stock Exchange of Thailand (SET) and the Market for Alternative Investment (MAI) as of the year ended 2009, and all of them use budget for performance evaluation. The companies in financial industry and companies under rehabilitation are excluded since their financial reporting requirements and their characteristics of business operation are different. Also, this study chooses to employ the cross-sectional modified Jones (1995) model that is not applicable to measure discretionary accruals of the companies in financial industry. Besides, the companies must have been listed on the SET or MAI for at least 1 year before the end of 2009 since it is presumed that the listed companies usually use budget more effectively in planning, control, and performance evaluation than the non-listed companies. The population covers 387 firms and there are 38 returned and usable questionnaires which is $10 \%$ response rate. Detail of population and final sample firm breakdown by industry is presented in Part I of Appendix A and detail of returned 
questionnaires is presented in Part II of Appendix A.

The survey questionnaires (Thai version) are administered and sent to the firms' management who held one of the following titles: Chief Financial Officer, Controller, Vice President, Managing Director, or Manager. These respondents have to work with the firms since or prior to 2009, involve extensively in budgeting process, and are accountable for the firms' performance. The annual financial statements are retrieved from the SET Market Analysis and Reporting Tool ("SETSMART").

387 mailed survey questionnaires are distributed during May-June 2011 and designed to elicit information on budget figures of the year 2009, respondents' perceptions of the achievability of their annual earnings targets, and all determinants of budgetary slack.

From the initial sample set, the firms with no or invalid data on actual or budgeted earnings are excluded. The final sample set comprises 38 firms (equivalent to $10 \%$ of total population). The small sample size is due to the difficulty in obtaining the firms' internal and confidential data. Demographic profile of respondents is presented in Appendix B.

\section{B. Measures}

As budgetary slack is not directly observable, prior survey studies usually measure budgetary slack subjectively, i.e., "the achievability of performance targets as perceived by managers". Although it is a perceptual dependent variable, prior survey studies usually measure budgetary slack in this manner.

In this study, the ex post measure of annual firms' budget achievability has been introduced to objectively measure budgetary slack. The rationale behind using the achievability of annual performance targets (variances between actual and budget amounts) to proxy for budgetary slack is that the more the slack build into budget, the higher the propensity to easily achieve the budget.

When subordinates create slack into budget, they choose more easily attainable standard. The subordinates engage in this behavior in the hope that the standard or budget which their performance is evaluated would be more easily achieved. In other words, if the subordinates set the easily attainable budgets, they would generate the favorable variances. Hence, it could be said that the more favorable the variances, the more the budgetary slack.

Ref. [8] Measure budget achievability by comparing past and current-year performances with budget targets. Besides, [21] use prior year's performance relative to its target as a proxy for a prior period's organizational slack.

The development of the proxy of budgetary slack in this study is as follows:

Net Income $=$ Cash Flow from Operations + Total Accruals $=\mathrm{CFO}+$ (Nondiscretionary Accruals + Discretionary Accruals)

Discretionary Accruals is identified as Earnings Management, EM. See more detail of earnings management models to estimate NDA and DA in Appendix C.

Budget achievability (including EM, if any) = Actual NI Budgeted NI $=(\mathrm{CFO}+\mathrm{NDA}+\mathrm{DA})-$ Budgeted NI

Exclude DA from both sides

Budget achievability $-\mathrm{DA}=(\mathrm{CFO}+\mathrm{NDA}+\mathrm{DA})-\mathrm{DA}-$

\section{Budgeted NI}

Hence

Budget achievability (excluding EM, if any $)=(\mathrm{CFO}+$ NDA) - Budgeted NI

Budget achievability (excluding EM, if any) is introduced in this study to proxy budgetary slack as it shows budget achievability before discretionary accruals in managing earnings. Next, dividing the budget achievability (excluding $\mathrm{EM}$, if any) level by the original budget figure to obtain a percentage of budget achievability before earnings management. Then, rescaling the percentage values to be all positive numbers (for the reason of simple computation and reasonable value of slack; however, there is no effect on statistical analysis) to determine the objective measurement of budgetary slack (SLACKNEW).

For traditional subjective slack measurements, this study employs the survey questions used in prior studies to subjectively measure budgetary slack.

The first subjective measurement (SLACK1) is "perceived ease of budget achievability". The survey question is "the annual budget targets are generally (i) very easy to attain; (ii) attainable with reasonable effort; (iii) attainable with considerable effort; (iv) practically unattainable; or (v) impossible to attain". Each respondent is asked to specify the percentage of, rather than the five- or seven-point Likert scale, the level of perceived ease in achieving budget.

The second subjective measurement (SLACK2) is "perceived difficulty of budget achievability". The survey questions are (i) "annual budget targets induce high productivity in your business unit", and (ii) "budget targets require costs to be managed carefully in your business unit", both of which are reverse coded. Similar to SLACK1, each respondent is asked to specify the percentage of, rather than the five- or seven-point Likert scale, the level of perceived difficulty in achieving budget.

\section{RESUlTS}

\section{A. Descriptive Statistics}

Table I presents descriptive statistics of final sample. Cronbach's Alpha of all certain variables exceeds the conventional value of 0.7 [22], so that the reliability of measurements is ensured. Among the three measures of budgetary slack, the mean (median) of subjective budgetary slack measurements, SLACK1, is the highest at $61.71 \%(65 \%)$ and SLACK2's is reasonably low at $25.64 \%(20 \%)$, while that of the objective measurement, SLACKNEW, is the lowest at $8.49 \%(7.40 \%)$.

With respect to environmental factor, the mean (median) of environmental uncertainty, ENVI, at $36.32 \%$ (33.33\%) implies that, on average, the respondents perceive high predictability of firms' economic environment. For organizational factors, the mean (median) of information asymmetry, INFO, at $35.68 \%$ (34\%) indicates moderate level of asymmetric information between respondents and their superiors, while those of budget emphasis evaluative style, BUDEM, and participative styles, PARTI, at 63.33\% (62.50\%) and 7.37 (8.13) of 10, respectively, reveal that superiors place considerably high emphasis on meeting the budget and they also allow their subordinates to actively participate in 
budgeting process. For reward systems, REWA, the mean (median) of objective performance measures, $O B J$, is $39.55 \%$ $(50 \%)$, indicating that respondents' compensation is roughly equally weighted between objective and subjective measures, while those of financial, FIN, budget-based, BUD, and controllable, $C O N$, performance measures are $67.42 \%(70 \%)$, $66.45 \%(70 \%)$, and $69.64 \%$ (70\%), respectively, indicating that those performance measures are heavily weighted to respondents' total compensation. The indicating variable of budget-based resource allocation, $A L L O$, shows a mean of 0.95 , indicating that $95 \%$ of the sample firms use budget for both planning and control purposes. With respect to individual factors, the mean (median) of ethical concerns, ETHICS, is $29.85 \%(28.33 \%)$ which implies that the respondents' ethical reasoning is moderately low, and that of reputation concerns, REPU, at $76.41 \%$ (80\%) suggests respondents' obvious desire to appear honest and fair to their superiors. The mean (median) of fairness concerns, FAIR, at $36.09 \%$ (35\%) shows respondents' perceived inconsiderable fairness of the budgeting environment.

TABLE I: DESCRIPTIVE STATISTICS

\begin{tabular}{|c|c|c|c|c|c|c|c|}
\hline Variables & $\begin{array}{c}\text { No. of } \\
\text { questions }\end{array}$ & Alpha & Mean & Median & SD & Min & Max \\
\hline \multicolumn{8}{|l|}{$\begin{array}{l}\text { Budgetary Slack } \\
\text { nack }\end{array}$} \\
\hline SLACK1 & 1 & NA & 61.71 & 65.00 & 13.37 & 35 & 85 \\
\hline SLACK2 & 2 & 0.87 & 25.64 & 20.00 & 15.72 & 0 & 80 \\
\hline SLACKNEW & 2 & $\mathrm{NA}$ & 8.49 & 7.40 & 8.42 & 0 & 54 \\
\hline \multicolumn{8}{|l|}{ Environmental Factor } \\
\hline Environmental Uncertainty (ENVI) & 6 & 0.77 & 36.32 & 33.33 & 18.66 & 5 & 100 \\
\hline \multicolumn{8}{|l|}{ Organizational Factors } \\
\hline Information Asymmetry (INFO) & 5 & 0.85 & 35.68 & 34.00 & 15.80 & 4 & 67 \\
\hline Budget Emphasis Evaluative Style (BUDEM) & 3 & 0.70 & 63.33 & 62.50 & 21.40 & 5 & 100 \\
\hline Participative Styles (PARTI) & 1 & NA & 7.37 & 8.13 & 3.60 & 0 & 10 \\
\hline \multicolumn{8}{|l|}{ Reward Systems (REWA) } \\
\hline Objective Performance Measures $(O B J)$ & 1 & NA & 39.55 & 50.00 & 32.02 & 0 & 100 \\
\hline Financial Performance Measures (FIN) & 1 & NA & 67.42 & 70.00 & 20.81 & 20 & 100 \\
\hline Budget-based Performance Measures (BUD) & 1 & NA & 66.45 & 70.00 & 27.15 & 0 & 100 \\
\hline Controllable Performance Measures $(\mathrm{CON})$ & 1 & NA & 69.64 & 70.00 & 23.49 & 10 & 100 \\
\hline Budget-based Resource Allocation (ALLO) & 2 & NA & 0.95 & 1.00 & 0.23 & 0 & 1 \\
\hline \multicolumn{8}{|l|}{ Individual Factors } \\
\hline Ethical Concerns (ETHICS) & & NA & 29.85 & 28.33 & 11.43 & 7 & 50 \\
\hline Reputation Concerns (REPU) & 4 & 0.85 & 76.41 & 80.00 & 15.67 & 30 & 95 \\
\hline Fairness Concerns (FAIR) & 4 & 0.94 & 36.09 & 35.00 & 16.37 & 10 & 88 \\
\hline \multicolumn{8}{|l|}{ Control Variables } \\
\hline Ln_size & & & 15.08 & 14.83 & 1.58 & 13.12 & 19.37 \\
\hline LISTED & & & 0.08 & 0.00 & 0.27 & 0 & 1 \\
\hline CONSOL & & & 0.29 & 0.00 & 0.46 & 0 & 1 \\
\hline
\end{tabular}

Slack 1-traditional measurement of slack (perceived ease of budget achievability);

Slack 2-traditional measurement of slack (reversed score of perceived difficulty of budget achievability);

Slack New-New measurement of slack ([budget achievability discretionary accruals] / original budget figure);

Environmental Uncertainty - reversed score of perceived predictability of firms' economic environment;

Information Asymmetry-level of information asymmetry between respondents and their superiors;

Budget Emphasis Evaluative Style - level of budget emphasis which respondents are evaluated by their superiors;

Participative Styles-level of participation in which respondents are allowed in budgeting process;

Reward Systems - relative weight on each type of reward systems which are based on (1) objective performance measures, (2) financial performance measures, (3) budget-based performance measures, and (4) controllable performance measures;

Budget-based Resource Allocation-indicator variable for firms that use budget for both planning and control purposes;

Ethical Concerns - respondents' ethical concerns level;

Reputation Concerns - respondents' desire to appear honest and fair to their superiors;

Fairness Concerns - perceived fairness of the budgeting environment;

LnSize - natural log of total assets at the beginning of the year;

Listed - indicator variable for company listed on MAI;

Consolidated - indicator variable for consolidated financial statements.
With respect to control variables, the mean of natural log of total assets at the beginning of the year, Ln_size, of the sample firms is 15.08 (THB 15,746 million, not tabulated), while indicating variables of stock exchange of the firm listing, LISTED, and consolidated financial statements, CONSOL, present a mean of 0.08 and 0.29 , respectively, indicating that $8 \%$ of the sample firms are listed on MAI and $29 \%$ of them evaluate respondents' performance based on the consolidated financial statements.

\section{B. Correlation Matrix}

Table II shows correlations among variables in this study. The Pearson's correlation coefficient between SLACK2 and $S L A C K N E W$ is significantly positive $(\mathrm{r}=0.58, \mathrm{p}<0.01)$ as expected, but the correlation coefficients between $S L A C K 1$ and SLACKNEW and between SLACK1 and SLACK2 are insignificant.

TABLE II: CORRELATION MATRIX

\begin{tabular}{cc|ccc}
\hline \hline Variables & & SLACK1 & SLACK2 & SLACK NEW \\
\hline SLACK1 & Correlation & 1.00 & 0.11 & -0.17 \\
& p-value & - & $(0.50)$ & $(0.31)$ \\
& $\mathbf{n}$ & 38 & 38 & 38 \\
SLACK2 & Correlation & & 1.00 & $\mathbf{0 . 5 8 * * *}$ \\
& p-value & & - & $(\mathbf{0 . 0 0})$ \\
& $\mathbf{n}$ & & 38 & 38 \\
SLACKNEW & Correlation & & & 1.00 \\
& p-value & & & - \\
& $\mathbf{n}$ & & & 38 \\
\hline \hline
\end{tabular}

Corresponding two-tailed $\mathrm{p}$-values are reported in parentheses. *** indicates significance at the $1 \%$ level.

TABLE III: REGRESSION RESULTS OF SLACK1

\begin{tabular}{|c|c|c|c|c|c|c|}
\hline \multirow{3}{*}{$\begin{array}{c}\text { Interesting } \\
\text { Variables }\end{array}$} & \multicolumn{6}{|c|}{ SLACKI } \\
\hline & \multirow[b]{2}{*}{ Constant } & \multirow[b]{2}{*}{ Coeff. } & \multicolumn{3}{|c|}{ Control Variables } & \multirow[b]{2}{*}{$\operatorname{Adj} R^{2}$} \\
\hline & & & Ln_size & LISTED & CONSOL & \\
\hline$E N V I$ & $\begin{array}{c}111.58 * * * \\
(0.00)\end{array}$ & $\begin{array}{l}0.23 * \\
(0.06)\end{array}$ & $\begin{array}{c}-4.06 \\
(0.13)\end{array}$ & $\begin{array}{l}2.34 \\
(0.81)\end{array}$ & $\begin{array}{c}4.54 \\
(0.51)\end{array}$ & $1 \%$ \\
\hline INFO & $\begin{array}{c}61.22 * * \\
(0.02)\end{array}$ & $\begin{array}{c}0.31 * * \\
(0.02)\end{array}$ & $\begin{array}{l}-0.68 \\
(0.69)\end{array}$ & $\begin{array}{l}2.66 \\
(0.76)\end{array}$ & $\begin{array}{l}-0.58 \\
(0.92)\end{array}$ & $6 \%$ \\
\hline BUDEM & $\begin{array}{c}66.47 * \\
(0.06)\end{array}$ & $\begin{array}{c}0.07 \\
(0.61)\end{array}$ & $\begin{array}{l}-0.57 \\
(0.78)\end{array}$ & $\begin{array}{l}3.73 \\
(0.69)\end{array}$ & $\begin{array}{l}-2.32 \\
(0.72)\end{array}$ & $4 \%$ \\
\hline PARTI & $\begin{array}{c}58.44 * * \\
(0.03)\end{array}$ & $\begin{array}{l}-1.25 * \\
(0.07)\end{array}$ & $\begin{array}{c}0.90 \\
(0.62)\end{array}$ & $\begin{array}{l}7.80 \\
(0.38)\end{array}$ & $\begin{array}{l}-1.75 \\
(0.75)\end{array}$ & $11 \%$ \\
\hline$O B J$ & $\begin{array}{c}67.61 * * \\
(0.04)\end{array}$ & $\begin{array}{c}0.07 \\
(0.39)\end{array}$ & $\begin{array}{l}-0.59 \\
(0.77)\end{array}$ & $\begin{array}{l}6.50 \\
(0.53)\end{array}$ & $\begin{array}{l}-2.63 \\
(0.67)\end{array}$ & $7 \%$ \\
\hline$F I N$ & $\begin{array}{c}76.72 * \\
(0.06)\end{array}$ & $\begin{array}{c}0.16 \\
(0.24)\end{array}$ & $\begin{array}{l}-1.77 \\
(0.49)\end{array}$ & $\begin{array}{l}4.25 \\
(0.68)\end{array}$ & $\begin{array}{c}0.78 \\
(0.92)\end{array}$ & $10 \%$ \\
\hline$B U D$ & $\begin{array}{c}82.06 * * \\
(0.05)\end{array}$ & $\begin{array}{c}0.01 \\
(0.92)\end{array}$ & $\begin{array}{l}-1.44 \\
(0.58)\end{array}$ & $\begin{array}{l}3.24 \\
(0.75)\end{array}$ & $\begin{array}{l}-0.98 \\
(0.89)\end{array}$ & $5 \%$ \\
\hline CON & $\begin{array}{c}86.98 * * \\
(0.03)\end{array}$ & $\begin{array}{c}0.20 \\
(0.11)\end{array}$ & $\begin{array}{l}-2.78 \\
(0.32)\end{array}$ & $\begin{array}{l}1.66 \\
(0.87)\end{array}$ & $\begin{array}{c}3.40 \\
(0.66)\end{array}$ & $0 \%$ \\
\hline$A L L O$ & $\begin{array}{c}89.84 * * * \\
(0.00)\end{array}$ & $\begin{array}{l}-10.39 \\
(0.16)\end{array}$ & $\begin{array}{l}-1.21 \\
(0.50)\end{array}$ & $\begin{array}{l}3.54 \\
(0.70)\end{array}$ & $\begin{array}{l}-1.19 \\
(0.83)\end{array}$ & $6 \%$ \\
\hline ETHICS & $\begin{array}{l}57.52 \\
(0.11)\end{array}$ & $\begin{array}{l}-0.09 \\
(0.34)\end{array}$ & $\begin{array}{c}0.43 \\
(0.86)\end{array}$ & $\begin{array}{l}5.49 \\
(0.56)\end{array}$ & $\begin{array}{c}1.32 \\
(0.84)\end{array}$ & $3 \%$ \\
\hline REPU & $\begin{array}{c}81.88 * * * \\
(0.01)\end{array}$ & $\begin{array}{l}-0.04 \\
(0.41)\end{array}$ & $\begin{array}{l}-1.16 \\
(0.52)\end{array}$ & $\begin{array}{l}2.77 \\
(0.77)\end{array}$ & $\begin{array}{l}-0.51 \\
(0.93)\end{array}$ & $3 \%$ \\
\hline FAIR & $\begin{array}{c}72.83 * * * \\
(0.01)\end{array}$ & $\begin{array}{l}-0.09 \\
(0.30)\end{array}$ & $\begin{array}{l}-0.51 \\
(0.81)\end{array}$ & $\begin{array}{l}4.58 \\
(0.64)\end{array}$ & $\begin{array}{l}-2.23 \\
(0.73)\end{array}$ & $4 \%$ \\
\hline
\end{tabular}

\section{Regression Results}

Table III-Table $\mathrm{V}$ presents the regression results of the association between each budgetary slack measurement and its determinants. For $S L A C K 1$, the adjusted $\mathrm{R}^{2}$ in general falls between $0 \%-11 \%$, which is slightly less than that of $S L A C K 2$ which is in range of $1 \%-21 \%$. The highest adjusted $\mathrm{R}^{2}$ belongs to $S L A C K N E W$ which falls between $2 \%$ $24 \%$. In sum, the adjusted $\mathrm{R}^{2}$ of $S L A C K N E W$ in nearly all 
models are far greater than those of both SLACK1 and $S L A C K 2$, and the adjusted $\mathrm{R}^{2}$ of $S L A C K 2$ in several models are more than those of $S L A C K 1$, which mean that explanatory variables are able to explain and predict the objective measurement of budgetary slack (SLACKNEW) better than those two traditional subjective measurements (SLACK1 and $S L A C K 2$ ) and among the two subjective measurements, $S L A C K 2$ is more superior than SLACK1.

TABLE IV: REGRESSION RESULTS OF SLACK2

\begin{tabular}{|c|c|c|c|c|c|c|}
\hline \multirow{3}{*}{$\begin{array}{c}\text { Interesting } \\
\text { Variables }\end{array}$} & \multicolumn{6}{|c|}{ SLACK2 } \\
\hline & \multirow[b]{2}{*}{ Constant } & \multirow[b]{2}{*}{ Coeff. } & \multicolumn{3}{|c|}{ Control Variables } & \multirow[b]{2}{*}{$\operatorname{Adj} R^{2}$} \\
\hline & & & Ln_size & LISTED & CONSOL & \\
\hline \multirow[t]{2}{*}{ ENVI } & 19.78 & $0.40 * * *$ & -0.54 & 12.58 & -5.84 & $14 \%$ \\
\hline & $(0.48)$ & $(0.00)$ & $(0.78)$ & $(0.21)$ & $(0.34)$ & \\
\hline \multirow[t]{2}{*}{ INFO } & 19.19 & $0.23 *$ & -0.19 & 15.06 & 0.05 & $1 \%$ \\
\hline & $(0.46)$ & $(0.08)$ & $(0.91)$ & $(0.14)$ & $(0.99)$ & \\
\hline \multirow[t]{2}{*}{ BUDEM } & $81.29 * *$ & $-0.33 * *$ & -2.39 & 4.43 & 3.03 & $7 \%$ \\
\hline & $(0.04)$ & $(0.02)$ & $(0.29)$ & $(0.66)$ & $(0.67)$ & \\
\hline \multirow[t]{2}{*}{ PARTI } & -34.77 & -1.18 & $4.88 *$ & 17.06 & $-13.99 *$ & $3 \%$ \\
\hline & $(0.39)$ & $(0.17)$ & (0.10) & $(0.14)$ & $(0.08)$ & \\
\hline \multirow[t]{2}{*}{$O B J$} & -20.86 & 0.05 & 2.97 & $16.78 *$ & $-12.89 * *$ & $6 \%$ \\
\hline & $(0.54)$ & $(0.52)$ & $(0.19)$ & $(0.08)$ & $(0.05)$ & \\
\hline \multirow[t]{2}{*}{ FIN } & 4.76 & 0.16 & 0.55 & 13.15 & -7.24 & $7 \%$ \\
\hline & $(0.89)$ & $(0.17)$ & $(0.81)$ & $(0.13)$ & $(0.26)$ & \\
\hline \multirow[t]{2}{*}{$B U D$} & 24.48 & -0.12 & 0.76 & 8.52 & -13.00 & $2 \%$ \\
\hline & $(0.59)$ & $(0.31)$ & $(0.80)$ & $(0.45)$ & $(0.12)$ & \\
\hline \multirow[t]{2}{*}{ CON } & -5.80 & 0.05 & 1.90 & 12.74 & -10.20 & $3 \%$ \\
\hline & $(0.86)$ & $(0.67)$ & $(0.41)$ & $(0.13)$ & $(0.13)$ & \\
\hline \multirow[t]{2}{*}{$A L L O$} & 25.45 & -2.05 & 0.05 & 8.45 & -2.38 & $4 \%$ \\
\hline & $(0.37)$ & $(0.42)$ & $(0.98)$ & $(0.35)$ & $(0.67)$ & \\
\hline \multirow[t]{2}{*}{ ETHICS } & -7.88 & $-0.41 *$ & 3.15 & 12.75 & -11.49 & $6 \%$ \\
\hline & $(0.85)$ & $(0.06)$ & $(0.26)$ & $(0.25)$ & $(0.15)$ & \\
\hline \multirow[t]{2}{*}{ REPU } & $69.41 * * *$ & $-0.44 * * *$ & -0.81 & 3.30 & 1.04 & $21 \%$ \\
\hline & $(\mathbf{0 . 0 1 )}$ & $(0.00)$ & $(0.60)$ & $(0.68)$ & $(0.83)$ & \\
\hline \multirow[t]{2}{*}{ FAIR } & 23.75 & 0.02 & 0.13 & 6.98 & -4.35 & $3 \%$ \\
\hline & $(0.48)$ & $(0.47)$ & $(0.96)$ & $(0.54)$ & $(0.56)$ & \\
\hline
\end{tabular}

Corresponding two-tailed p-values are reported in parentheses.

$* * *, * * *$ indicate significance at the $1 \%, 5 \%$ and $10 \%$ levels, respectively.

Environmental Uncertainty - reversed score of perceived predictability of firms' economic environment;

Information Asymmetry-level of information asymmetry between respondents and their superiors;

Budget Emphasis Evaluative Style-level of budget emphasis which respondents are evaluated by their superiors;

Participative Styles - level of participation in which respondents are allowed in budgeting process;

Reward Systems - relative weight on each type of reward systems which are based on (1) objective performance measures, (2) financial performance measures, (3) budget-based performance measures, and (4) controllable performance measures;

Budget-based Resource Allocation-indicator variable for firms that use budget for both planning and control purposes;

Ethical Concerns - respondents' ethical concerns level;

Reputation Concerns - respondents' desire to appear honest and fair to their superiors;

Fairness Concerns - perceived fairness of the budgeting environment;

LnSize - natural log of total assets at the beginning of the year;

Listed -indicator variable for company listed on MAI;

Consolidated - indicator variable for consolidated financial statements.

In summary, the determinant factor that significantly associates with all three measurements of budgetary slack is environmental uncertainty. In other words, the association between environmental uncertainty and budgetary slack is insensitive to the measurements of slack. The determinant factors that significantly associate with two (of three) measurements of budgetary slack are information asymmetry, budget emphasis evaluative style and participative styles. It could be said that the association between those factors and budgetary slack are relatively sensitive to the measurements of slack. Moreover, this study also reports that budget-based resource allocation, $A L L O$, is insignificant regardless of budgetary slack measurements. For reward systems, only budget-based performance measure, $B U D$, is significantly associated with the objective measurement of budgetary slack, SLACKNEW. The determinant factors that significantly associate with only one measurement of budgetary slack are ethical concerns, reputation concerns and fairness concerns. It could be said that the association between those factors and budgetary slack are very sensitive to the measurements of slack. Overall, the association between budgetary slack and its determinants is sensitive to the measurements of slack, i.e., objective or subjective measurements or even between the two subjective measurements. However, the objective measurement of budgetary slack suggested in this study generates higher adjusted $\mathrm{R}^{2}$ than the two subjective measurements do. This may imply that the objective measurement suggested in this study is a better measurement of slack, and among those two subjective measurements, $S L A C K 2$ is more superior than $S L A C K 1$ seeing that $S L A C K 2$ generally produce higher adjusted $\mathrm{R}^{2}$.

TABLE V: REGRESSION RESULTS OF SLACKNEW

\begin{tabular}{|c|c|c|c|c|c|c|}
\hline \multirow{3}{*}{$\begin{array}{c}\text { Interesting } \\
\text { Variables }\end{array}$} & \multicolumn{6}{|c|}{ "SLACKNEW } \\
\hline & \multirow[b]{2}{*}{ Constant } & \multirow[b]{2}{*}{ Coeff. } & \multicolumn{3}{|c|}{ Control Variables } & \multirow[b]{2}{*}{$\operatorname{Adj} \mathbf{R}^{2}$} \\
\hline & & & $\overline{L n \_ \text {size }}$ & LISTED & CONSOL & \\
\hline$E N V I$ & 0.20 & $\begin{array}{l}\mathbf{0 . 0 5}^{*} \\
(\mathbf{0 . 0 8})\end{array}$ & -0.14 & $6.52 * * *$ & 0.37 & $24 \%$ \\
\hline INFO & $\begin{array}{c}2.18 \\
(0.74)\end{array}$ & $\begin{array}{l}-0.01 \\
(0.43)\end{array}$ & $\begin{array}{l}-0.16 \\
(0.70)\end{array}$ & $\begin{array}{c}\text { 6.16**** } \\
(0.01)\end{array}$ & $\begin{array}{c}0.15 \\
(0.91)\end{array}$ & $17 \%$ \\
\hline BUDEM & $\begin{array}{l}20.64 \\
(0.35)\end{array}$ & $\begin{array}{c}-0.17 * * \\
(0.03)\end{array}$ & $\begin{array}{l}-0.59 \\
(0.67)\end{array}$ & $\begin{array}{l}5.17 \\
(0.36)\end{array}$ & $\begin{array}{c}0.61 \\
(0.88)\end{array}$ & $7 \%$ \\
\hline PARTI & $\begin{array}{l}-12.15 \\
(0.55)\end{array}$ & $\begin{array}{c}-0.72 * \\
(0.09)\end{array}$ & $\begin{array}{c}1.28 \\
(0.37)\end{array}$ & $\begin{array}{l}8.85 \\
(0.14)\end{array}$ & $\begin{array}{l}-3.81 \\
(0.33)\end{array}$ & $2 \%$ \\
\hline$O B J$ & $\begin{array}{l}-1.19 \\
(0.87)\end{array}$ & $\begin{array}{c}0.01 \\
(0.51)\end{array}$ & $\begin{array}{c}0.03 \\
(0.95)\end{array}$ & $\begin{array}{c}6.91 * * * * \\
(0.01)\end{array}$ & $\begin{array}{l}-0.88 \\
(0.53)\end{array}$ & $22 \%$ \\
\hline FIN & $\begin{array}{l}-3.52 \\
(0.69)\end{array}$ & $\begin{array}{c}0.02 \\
(0.53)\end{array}$ & $\begin{array}{c}0.14 \\
(0.81)\end{array}$ & $\begin{array}{c}6.98 * * * \\
(0.01)\end{array}$ & $\begin{array}{l}-0.98 \\
(0.57)\end{array}$ & $21 \%$ \\
\hline$B U D$ & $\begin{array}{c}9.09 \\
(0.71)\end{array}$ & $\begin{array}{l}-0.11 * \\
(0.10)\end{array}$ & $\begin{array}{c}0.06 \\
(0.97)\end{array}$ & $\begin{array}{l}4.27 \\
(0.50)\end{array}$ & $\begin{array}{l}-4.49 \\
(0.33)\end{array}$ & $2 \%$ \\
\hline CON & $\begin{array}{l}-2.87 \\
(0.79)\end{array}$ & $\begin{array}{l}-0.02 \\
(0.56)\end{array}$ & $\begin{array}{c}0.29 \\
(0.71)\end{array}$ & $\begin{array}{c}6.86 * * * \\
(0.01)\end{array}$ & $\begin{array}{l}-1.69 \\
(0.43)\end{array}$ & $19 \%$ \\
\hline$A L L O$ & $\begin{array}{c}2.81 \\
(0.68)\end{array}$ & $\begin{array}{l}-0.83 \\
(0.36)\end{array}$ & $\begin{array}{l}-0.17 \\
(0.69)\end{array}$ & $\begin{array}{c}6.20 * * * * \\
(0.01)\end{array}$ & $\begin{array}{c}0.18 \\
(0.89)\end{array}$ & $17 \%$ \\
\hline ETHICS & $\begin{array}{l}-7.12 \\
(0.40)\end{array}$ & $\begin{array}{c}0.07 \\
(0.11)\end{array}$ & $\begin{array}{c}0.34 \\
(0.55)\end{array}$ & $\begin{array}{c}6.96 * * * \\
(0.00)\end{array}$ & $\begin{array}{l}-0.59 \\
(0.72)\end{array}$ & $22 \%$ \\
\hline REPU & $\begin{array}{c}1.64 \\
(0.82)\end{array}$ & $\begin{array}{l}-0.02 \\
(0.34)\end{array}$ & $\begin{array}{l}-0.06 \\
(0.88)\end{array}$ & $\begin{array}{c}6.09 * * * \\
(0.01)\end{array}$ & $\begin{array}{c}0.59 \\
(0.66)\end{array}$ & $18 \%$ \\
\hline FAIR & $\begin{array}{l}-2.09 \\
(0.74)\end{array}$ & $\begin{array}{c}-0.07 * * \\
(0.04)\end{array}$ & $\begin{array}{c}0.28 \\
(0.55)\end{array}$ & $\begin{array}{c}7.22 * * * \\
(0.00)\end{array}$ & $\begin{array}{l}-0.85 \\
(0.55)\end{array}$ & $24 \%$ \\
\hline
\end{tabular}

\section{CONCLUSION}

As prior survey studies usually measure budgetary slack from a subjective view which considered as a problematic measurement as it is sensitive to the respondents' judgment. Therefore, this study introduces an objective approach to measure budgetary slack, i.e., the ex post measure of firm's annual budget achievability with the exclusion of discretionary accruals.

The empirical results in this study are generated from both primary and secondary data of 38 firms in Thailand. The data on the budget figures of the year 2009, perceived budget achievability and budgetary slack's determinants are garnered from corporate executives of the listed non-financial firms in Thailand to match their firms' annual financial statements. In assessing discretionary accruals, the cross-sectional modified Jones (1995) model is employed, and for robustness test, the cross-sectional Jones (1991) model is utilized. 
The results show that the objective measurement and the subjective measurement (reversed score of perceived difficulty of budget achievability) of budgetary slack are statistically positively correlated $(\mathrm{r}=0.58, \mathrm{p}<0.01)$. Even though the objective and the subjective measurement of budgetary slack are significantly and positively correlated, we still consider that the suggested objective approach of budgetary slack measurement proposed in this study makes available another objective measurement of slack. However, the other subjective measurement (perceived ease of budget achievability) is insignificantly correlated. The differences in measurements of budgetary slack might be the cause of inconclusive results of the association between budgetary slack and its determinants in prior research. This study; therefore, empirically investigates the association between budgetary slack and its determinants by comparing the objective and the subjective slack measurements. The results advocate that the association between budgetary slack and its determinants is sensitive to the measurements of slack, i.e., objective or subjective measurements or even between the two subjective measurements. However, the objective measurement of budgetary slack suggested in this study generates higher adjusted $\mathrm{R}^{2}$, in nearly all models, than the two subjective measurements do. These results indicate that the explanatory variables could explain and predict the objective measurement of budgetary slack better than the two subjective measurements. The results imply that the objective measurement, i.e., the ex post measure of firm's annual budget achievability with the exclusion of discretionary accruals, suggested in this study is a better measurement of budgetary slack than the traditional subjective measurements utilize in prior studies. Among the two subjective measurements of budgetary slack, SLACK2 (reversed score of the two questions about perceived difficulty of budget achievability) produces higher adjusted $\mathrm{R}^{2}$ than SLACK1 (simple question about perceived ease of budget achievability), these empirical results not only again reveal that the results are sensitive to the measurements of slack but also point out that number or attribute of the questions (simple or reverse questions) might be the cause of sensitivity and inconclusiveness.

Nevertheless, this empirical study is subject to a number of limitations. First, this study covers only the non-financial institutions listed in Thailand and the final set of samples is merely 38 firms due to the difficulty in obtaining the firms' internal and confidential data; hence, limiting generalizability of the results. Second, implicit assumptions in this study are that the ex post measure of annual firms' budget achievability with the exclusion of discretionary accruals is a good proxy for budgetary slack as the more the slack build into budget, the higher the propensity to easily achieve the budget, and the cross-sectional Modified Jones (1995) model accurately partitions accruals into its discretionary and nondiscretionary components. Third, measurement errors, model misspecifications and omitted variables may limit the reliability of results. Fourth, by the very nature of the survey data, this study relies primarily on self-reported responses to the survey questions in which the respondents are asked to recall their perceptions on budget achievability from the past to measure budgetary slack.

Despite the limitations, we still believe that this study adds prior literature an objective measurement of budgetary slack. Future research should endeavor to increase the sample size to improve generalizability of the results. Rather than a subjective measurement of budgetary slack, an objective measurement should be employed for further investigation in future studies. For robustness test, other earnings management categories and approaches, i.e., real earnings management and other accruals models, should be employed in estimating discretionary accruals.

\section{APPENDIX A}

Part I: Detail of population and final sample firms breakdown by industry

\begin{tabular}{|c|c|c|c|c|}
\hline Industry & Population & $\underline{\%}$ & $\begin{array}{c}\text { Final } \\
\underline{\text { Sample }}\end{array}$ & $\underline{\%}$ \\
\hline \multicolumn{5}{|l|}{ SET } \\
\hline Agribusiness and Food & 37 & $10 \%$ & 5 & 14 \\
\hline Consumer Products & 32 & $8 \%$ & 3 & $9 \%$ \\
\hline Industrials & 66 & $17 \%$ & 5 & $8 \%$ \\
\hline Property and & 74 & $19 \%$ & 8 & 11 \\
\hline Construction & & & & $\%$ \\
\hline Resources & 23 & $6 \%$ & 3 & $\begin{array}{l}13 \\
\%\end{array}$ \\
\hline Services & 80 & $21 \%$ & 5 & $6 \%$ \\
\hline Technology & 33 & $9 \%$ & 6 & 18 \\
\hline MAI & $\underline{42}$ & $\underline{11 \%}$ & $\underline{3}$ & $\underline{7 \%}$ \\
\hline Total & $\underline{\underline{387}}$ & $\frac{100}{\underline{\%}}$ & $\underline{\underline{38}}$ & $\frac{10}{\underline{0}}$ \\
\hline
\end{tabular}

There are two types of exchanges for listed firms in Thailand: SET (Stock Exchange of Thailand) and MAI (Market for Alternative Investment). SET provides a market for large companies with more than THB 300 million in paid-up capital after IPO to raise long- term funds. MAI, on the other hand, is a source of funding for small- and medium-sized enterprises, having over THB 20 million in paid-up capital after IPO.

\section{Part II: Detail of returned questionnaires}

$\begin{array}{ll}\text { Number of initially returned questionnaires } & 84 \\ \text { Less: } & \begin{array}{l}\text { New joiners (Respondents who work in } \\ \text { company after year 2009) }\end{array} \\ & -11 \\ & \text { Respondents who do not participate in } \\ \text { budgeting process } & -7 \\ & \begin{array}{l}\text { Respondents who do not provide budget } \\ \text { figures of } 2009\end{array} \\ & \begin{array}{l}\text { Companies that start to use budget less than } 3 \\ \text { years }\end{array} \\ & -16 \\ \text { Budget figure of year } 2009 \text { is not the data in } \\ \text { financial statement }\end{array}$

Number of final questionnaires 


\section{APPENDIX B}

\section{Demographic profile of respondents}

\begin{tabular}{|c|c|c|c|c|c|c|c|c|}
\hline \multicolumn{2}{|c|}{ Description } & \multirow[t]{2}{*}{$\mathbf{n}$} & \multirow[t]{2}{*}{$\%$} & \multirow[t]{2}{*}{ Mean } & \multirow[t]{2}{*}{ Median } & \multirow[t]{2}{*}{ SD } & \multirow[t]{2}{*}{ Min } & \multirow[t]{2}{*}{ Max } \\
\hline Sex & & & & & & & & \\
\hline & Male & 18 & $47 \%$ & & & & & \\
\hline & Female & 20 & $53 \%$ & & & & & \\
\hline \multicolumn{9}{|l|}{ Age } \\
\hline & Average (years) & & & 46 & 46 & 7.85 & 27 & 61 \\
\hline \multicolumn{9}{|l|}{ Education level } \\
\hline & Bachelor & 8 & $21 \%$ & & & & & \\
\hline & Master & 29 & $76 \%$ & & & & & \\
\hline & Doctor & 1 & $3 \%$ & & & & & \\
\hline \multicolumn{9}{|l|}{ Experience } \\
\hline Current position & Average (years) & & & 7 & 5 & 5.91 & 3 & 23 \\
\hline Current company & Average (years) & & & 12 & 10 & 7.86 & 3 & 30 \\
\hline
\end{tabular}

\section{APPENDIX C}

\section{Earnings Management}

Total Accruals $=$ Net Income - Cash Flow from Operations Measuring total accruals from the cash flows statement have less error than from the balance sheet account. [23] show an evidence of error and bias introduced by the balance sheet approach in estimated accruals to test for earnings management, particularly when non-operating events such as mergers and acquisitions or discontinuing operations occur. Therefore, measuring accruals directly from the statement of cash flows is a more appropriate measure.

Total accruals consist of two parts, nondiscretionary and discretionary accruals.

Total Accruals = Nondiscretionary Accruals + Discretionary Accruals (or TA = NDA + DA)

In this study, the cross-sectional modified Jones (1995) model is employed to measure discretionary accruals. We begin by estimating a cross-sectional variant of the Jones (1991) expected accruals model for all firms $i$ in industry $j$,

$$
\mathrm{TA} i j=\alpha j+\delta j(\Delta \mathrm{Rev})+\gamma j(\mathrm{PPE})+\varepsilon
$$

where

TA $i j$ is total accruals for firm $i$ in industry $j$ (Net Income before extraordinary items minus Cash Flow from Operations before extraordinary items);

$\Delta \mathrm{Revj}$ is the change in revenues between year $\mathrm{t}$ and year $\mathrm{t}-1$; and

PPE $j$ is gross property, plant and equipment.

Note that we use the industry classification based on that by the Stock Exchange of Thailand.

Next, for each firm $i j$ in the sample, we calculate the abnormal accruals, i.e., discretionary accruals (DA) which is defined as:

$$
\mathrm{DA} i j=\mathrm{TA} i j-[\alpha j+\delta j(\Delta \mathrm{Rev})+\gamma j(\mathrm{PPE})]
$$

where

$\alpha j, \delta j$, and $\gamma j$ are the fitted coefficients from Eq.(1).

All variables in all above equations are scaled by total assets at the beginning of the year.

Secondly, [24] propose the modified Jones model in which

$$
\mathrm{DA} i j=\mathrm{TA} i j-[\alpha j+\delta j(\Delta \mathrm{Rev}-\Delta \mathrm{Rec})+\gamma j(\mathrm{PPE})]
$$

The modification is that in the expected accruals model, revenue changes are adjusted for $\Delta \operatorname{Rec} j$, the change in receivables between year $\mathrm{t}$ and year $\mathrm{t}-1$. [24] calculate $\alpha j, \delta j$, and $\gamma j$ from the original Jones (1991) model, by modifying Eq.(1) to include the adjustment for receivables. The resulting value of the modified Jones (1995) model quantifies discretionary accruals.

\section{REFERENCES}

[1] C. W. Chow, J. C. Cooper, and K. Haddad, "The effects of pay schemes and ratchets on budgetary slack and performance: A multiperiod experiment," Accounting, Organizations and Society, pp. 47-60, 1991.

[2] P. Sumpunsirichareon, "The relationship between budgetary participation and budgeting effectiveness," Master's Thesis, Chulalongkorn University, BKK, Thailand, 2003.

[3] P. Chankaew, "Factors influencing budgetary slack," Master's Thesis Chulalongkorn University, BKK, Thailand, 2005.

[4] R. M. Cyert and J. C. March, "A behavioral theory of the firm," Englewood Cliffs, NJ: Prentice Hall, 1963.

[5] M. Schiff and A. Y. Lewin, "Where traditional budgeting fails," Financial Executive, pp. 281-301, 1968.

[6] D. E. Stevens, "The effects of reputation and ethics on budgetary slack," Journal of Management Accounting Research, vol. 14, pp. 153-171, 2002.

[7] W. A. V. der Stede, "The relationship between two consequences of budget control: Budgetary slack creation and managerial short-term orientation," Accounting, Organization and Society, vol. 25, no. 6, pp. 609-622, 2000.

[8] K. A. Merchant and J. F. Manzoni, "The achievability of budget targets in profit centers: A field study," The Accounting Review, vol. 64, no. 3, pp. 539-558, 1989.

[9] K. Lukka, "Budgetary biasing in organizations: Theoretical framework and empirical evidence," Accounting, Organization and Society, vol. 13, no. 3, pp. 281-302, 1988.

[10] M. Onsi, "Factor analysis of behavioral variables affecting budgetary slack," The Accounting Review, vol. 48, no. 3, pp. 535-548, 1973.

[11] K. Schipper, "Commentary on earnings management," Accounting Horizons, vol. 3, no. 4, pp. 91-102, 1989.

[12] P. M. Healy and J. M. Wahlen, "A review of the earnings management literature and its implications for standard setting," Accounting Horizons, vol. 13, pp. 365-383, 1999.

[13] P. M. Healy, "The effect of bonus schemes on accounting decisions," Journal of Accounting and Economics, vol. 7, pp. 85-107, 1985.

[14] M. L. D. Fond and J. Jiambalvo, "Debt covenant effects and the manipulation of accruals," Journal of Accounting and Economics, vol. 17, pp. 145-176, 1994.

[15] D. Burgstahler and I. Dichev, "Earnings management to avoid earnings decreases and losses," Journal of Accounting and Economics, vol. 24, pp. 99-126, 1997.

[16] K. G. Key, "Political cost incentives for earnings management in the cable television industry," Journal of Accounting and Economics, vol. 23, pp. 309-337, 1997.

[17] A. S. Dunk and H. Nouri, "Antecedent of budgetary slack: A literature review and synthesis," Journal of Accounting Literature, vol. 17, pp. 72-96, 1998 .

[18] J. G. Fisher, L. A. Maines, S. A. Peffer, and G. B. Sprinkle, "Using budgets for performance evaluation: Effects of resource allocation and horizontal information asymmetry on budget proposals, budget slack, and performance," The Accounting Review, vol. 77, no. 4, pp. 847-865, 2002.

[19] T. Libby, "The incentive effects of fairness: A study of effect of perceived fairness on budgetary slack and performance," Doctoral dissertation, University of Waterloo, 1996.

[20] K. A. Merchant, "Budgeting and the propensity to create budgetary slack," Accounting, Organizations and Society, vol. 10, no. 2, pp. 201-210, 1985.

[21] R. J. Indjejikian and M. Matejka, "Organizational slack in decentralized firms: The role of business unit controllers," The Accounting Review, vol. 81, no. 4, pp. 849-872, 2006.

[22] J. C. Nunnally, Psychometric Theory, 2nd ed., New York: McGraw-Hill, 1978.

[23] P. Hribar and D. Collins, "Errors in estimating accruals: Implications for empirical research," Journal of Accounting Research, vol. 40, pp. 105-134, 2002.

[24] P. M. Dechow, R. Sloan, and A. Sweeney, "Detecting earnings management," The Accounting Review, vol. 70, pp. 193-225, 1995. 


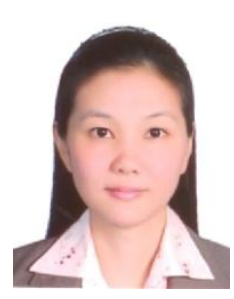

Pornpan Damrongsukniwat was born in Udonthani, Thailand, on December 17, 1978. She spent two and a half years to receive her bachelor's degree in business administration majoring in accounting (Second-Class Honors) from Ramkhamhaeng University, Bangkok, Thailand, in 1998. After completing her master's degree in accounting from Chulalongkorn University, Bangkok, Thailand, in 2002, she received the Certified Public Accountant (CPA) license from the Institute of Certified Accountants and Auditors of Thailand (ICAAT) in 2004. And she also received her bachelor's degree in laws from Sukhothai Thammathirat University, Bangkok, Thailand, in 2005. She received her doctoral degree in accounting from Chulalongkorn University, Bangkok, Thailand in 2012.

She had 5 years' experience with Pricewaterhouse Coopers ABAS Bangkok office, Thailand, in the audit and advisory profession. Currently, she is a LECTURER at the Department of Accounting, Faculty of Business Administration, Kasetsart University, Bangkok, Thailand. Her research interests include financial accounting and managerial accounting research.

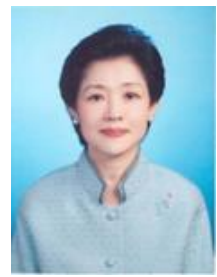

Danuja Kunpanitchakit was born in Bangkok, Thailand, on December 28, 1953. She received her bachelor's degree in accounting (First Class Honors, Gold Medal) from Chulalongkorn University, Bangkok, Thailand in 1976. She received her master's degree in business administration majoring in accounting from University of Wisconsin-Madison, U.S.A. in 1979. She received her doctoral degree in business administration from University of Wisconsin-Madison, U.S.A. in 1983.
She is an Associate Professor at the Department of Accountancy, Faculty of Commerce and Accountancy, Chulalongkorn University, Bangkok, Thailand. Currently, she is a VICE PRESIDENT, Chulalongkorn University, Bangkok, Thailand. Her research interests include managerial accounting and cost management research.

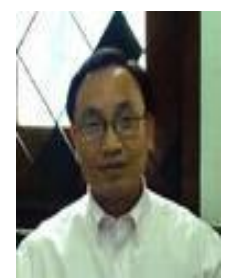

Supol Durongwatana was born in Bangkok, Thailand, on January 22, 1957. He received his bachelor's degree in statistics from Chulalongkorn University, Bangkok, Thailand in 1979. He received his master's degree in statistics from Oklahoma State University, U.S.A. in 1981. He received his doctora degree in statistics from Oklahoma State University, U.S.A. in 1984. Currently, he is an ASSOCIATE PROFESSOR at the Department of Statistics, Faculty of Commerce and Accountancy, Chulalongkorn University, Bangkok, Thailand. His research interests include statistical linear and non-linear models. 